\title{
ACCURACY ENHANCEMENT OF SRTM AND ASTER DEMS USING WEIGHT ESTIMATION REGRESSION MODEL
}

\author{
Hala Ebaid ${ }^{1}$ \\ ${ }^{I}$ Survey Research Institute, GIS Dept., 308 El Harm S., Giza, Egypt
}

\begin{abstract}
This paper assesses the accuracy of the SRTM $v 4.1$ and ASTER GDEM $v 2$ by comparing of sufficient number of ground control points (GCPs) with corresponding pixel values of DEMs heights for two locations in Egypt : Delta region(A) \&West desert and Qena region (B). A new approach was developed for accuracy enhancement based on (Weight Estimation Regression models) ,with Topographic Position Index(TPI), Aspect, SRTM or ASTER DEM as independent variables and GCP as dependent values . Data were analyzed for each location separately and in combination, using GIS and statistical software (SPSS). The results of this study showed that vertical Root Mean Square Errors (RMSE)for SRTM dataset range from $15.631 \mathrm{~m}$ in (A) to $7.868 \mathrm{~m}$ in (B). for ASTER dataset, RMSE ranges from $13.160 \mathrm{~m}$ in $(A)$ to $12.357 \mathrm{~m}$ in $(B)$.For combined regions $(A+B): R M S E$ were $12.688 \mathrm{~m}$ and $12.7997 \mathrm{~m}$ for SRTM and ASTER datasets respectively. Concerning the accuracy enhancement of SRTM and ASTER DEMs, a significant improvement of Std. Error of Estimate (SEE) were detected in the two locations. For (A) SEE reduce from 13.584 to 9.502 for SRTM dataset and reduce from 12.538 to 9.101 for ASTER dataset. For (B) SEE reduced from 7.879 to 1.725 for SRTM dataset and from 11.006 to 5.769 for ASTER dataset. Also for combined region SEE reduced from 11.685 to 5.930 for SRTM dataset, and from 11.7624to 8.520 for ASTER dataset. The study also proved that TPI index for ASTER dataset give the best fit to the data for Weight Estimation procedure for better horizontal resolution $(30 \mathrm{~m})$. The results of assessments and the improvement approaches of SRTM and ASTER DEMs showed their level of suitability for many hydraulic, watershed, and environment applications.
\end{abstract}

Keywords: DEM, SRTM, ASTER, GPS, Multiple regression line, Egypt

\section{INTRODUCTION}

DEMs play a major role in watershed modeling and hydrological flow (Renschler et al., 2002), evaluating erosion and environmental impact (Martinez-Casasnovas, 2003), and understanding spatial yield variability (Kravchenko and Bullock, 2000; Kaspar et al., 2003).

Originally released by the United States Geological Survey (USGS) in 2003, the Shuttle Radar Topographic Mission (SRTM) data contributes to the availability of homogeneous-quality elevation data around the world, especially for most tropical regions and developing countries (Bernhard et al. 2003). The SRTM digital elevation model (DEM) data have two spatial resolutions: 1" (about $30 \mathrm{~m}$ near the equator) in the United States and a 3" (about $90 \mathrm{~m}$ near the equator) outside the United States. Meanwhile, the accuracy of SRTM DEM data has been assessed across many regions, such as South America (Bernard and Nicolas 2005, Jarvis et al. 2008), the United States and Thailand (Gorokhovich and Voustianiouk 2006), Greece (George and Charalampos 2005) and globally (Berry et al. 2007) . Several publications on the accuracy of SRTM $90 \mathrm{~m}$ resolution elevation data, affirm that its absolute vertical accuracy is in the order of $\pm 16 \mathrm{~m}$.

The Advanced Spaceborne Thermal Emission and Reflection Radiometer (ASTER) global digital elevation model (GDEM) released by NASA and Japan's Ministry of Economy, Trade and Industry features a higher spatial resolution (1" ) and wider land coverage $\left(83^{\circ} \mathrm{N}-83^{\circ} \mathrm{S}\right)$ than the SRTM DEM. As the SRTM DEM has been successfully applied in many fields, the ASTER GDEM has gained much attention after its release in June 2009, but the accuracy of the newly released ASTER GDEM is primarily assessed in an official report. ASTER has an overall accuracy of around $17 \mathrm{~m}$ at the $95 \%$ confidence level, evaluated by the ASTER GDEM (ASTER GDEM Validation Team 2009).

The accuracy of the DEM is highly important for the applications based on the three dimensional model of the land. Accuracy of the DEM varies according to position accuracy, frequency, distribution of the source data used, land structure, and DEM generating (interpolation) methods.

Aiming at the improvement of the quality and accuracy of these free DEM, several efforts towards the direction of fusion of overlapping DEMs have been made. The DEM resulting from fusion methods should be geometrically accurate by depicting the correct height information of the area, clean by eliminating blunders and errors which are present in the initial data and complete by modelling all the area in the highest possible resolution( Papasaika and Baltsavias 2009). The multi-source DEMs usually have different characteristics, such as pixel size, height accuracy, etc., and are generated from data of different acquisition techniques and/or dates. For multi-source DEMs combination, a number of DEM fusion strategies have been proposed (Papasaika et al. 2011), (Honikel1999), (Gamba et al. 2003), (Podobnikar 2006). Among them, some strategies 
address the problem of fusion of DEMs produced by interferometric processing (Costantini et al. 2006).

Shi and Tian (2006) proposed a hybrid interpolation method that incorporates both the bilinear and the bi-cubic interpolation methods for DEM refinement. The weight of each interpolation method was defined by the complexity of the terrain. Although both procedures achieved some progress toward reliable and high-quality DEMs, they are not suitable for areas with surface discontinuities.

Different research test and investigate the influence of slope and Aspect on DEM accuracy. The effect of slope on SRTM accuracy was investigated by Sun et al. (2003) and the influence of aspect was described by Miliaresis and Paraschou (2005). Greater error values were associated with rugged terrain, while smaller error values were associated with coastal plain.

Multiple linear regression attempts to model the relationship between two or more explanatory variables and a response variable by fitting a linear equation to observed data. Every value of the independent variable is associated with a value of the dependent variable. Regression may be used in cases where interpolation is not effective because of insufficient sampling.

This paper comprises two stages: 1 . investigates and asses the accuracy of the SRTM v4.1 and ASTER GDEM v2 DEMs in two study areas with different topographic characteristics (Delta \& qena and west desert) by comparing elevation values from processed SRTM and ASTER with accurate GPS elevations .2. Develop a new approach for accuracy improvement of SRTM and ASTER DEM based on multiple regression analysis(Weight Estimation models) ,with Topographic Position Index(TPI), aspect ,open source DEM as independent variables and GCP as dependent values .

\section{STUDY AREA}

The study area Delta region (A) is located in Northern Egypt between latitudes $29.898 \mathrm{~N}$ and $31.17 \mathrm{~N}$ and longitude $29 \mathrm{E}$ and $32.6 \mathrm{E}$ with area about $45,000 \mathrm{~km}^{2}$. The study area West desert and Qena region (B) is located between latitudes $25.20 \mathrm{~N}$ and $27.45 \mathrm{~N}$ and longitude between 27.54 $\mathrm{E}$ and $34.14 \mathrm{E}$ with area about $150,000 \mathrm{~km}^{2}$ as shown in figure 1 . The study area (A) is broad, alluvial land, covered with vegetation and characterized by almost flat terrain and moderate hilly landscapes, and coastal plains, while study area B includes a hilly terrain with some steep slopes with ground level ranges from about 125 to $2114 \mathrm{~m}$ above mean sea level(amsl).
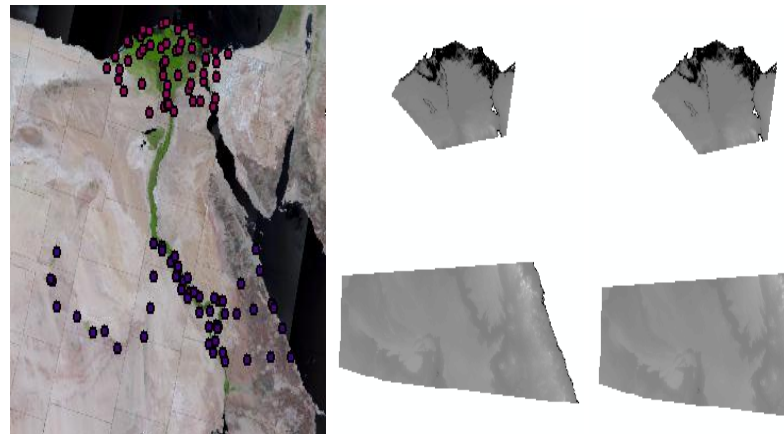

Fig 1: GCP distribution, SRTM DEM, and ASTER DEM for Delta \& qena and west Desert regions

\section{METHODOLOGY}

\subsection{GPS Data}

Among various methods of accuracy assessment, GPS survey provides the best way to map features on terrain with high accuracy. In this study, the GPS points have been observed (116 points for the two study areas (Delta \& Qena and west desart), by Egyptian Survey Research Institute using static GPS to obtain accurate three -dimensional coordinates (with a precision of 1 part per million) along with precise leveling techniques to measure orthometric heights (relative to MSL) based on Global geoid models (EGM96) .These GPS points were used to judge the accuracy of the two DEMs SRTM and ASTER for both regions.

\subsection{ASTER GDEM and SRTM Data}

The DEM acquired for the research was a $90 \mathrm{~m}$ spatial resolution SRTM version 4.1 which corresponds to the two study areas, which was downloaded from http://srtm.csi.cgiar.org., which it is available in 5 degree x 5 degree tiles, in Geographic decimal degrees projection, with WGS84 horizontal datum and EGM96 vertical datum. This version 4.1 was chosen for this research because it has been updated, and then released after using sophisticated interpolation and hole-filling algorithms (www.cgiarcsi.org).

Also The ASTER DEM version 2 corresponds to the same study areas. was downloaded from https://earthdata.nasa.gov/user, which are posted on a 1 arcsecond (approximately 30-m at the equator) grid, distributed as $1^{\circ} \times 1^{\circ}$ tiles and referenced to the World Geodetic System (WGS84)/1996 Earth Gravitational Model (EGM96) geoid. A 5-m overall bias observed in GDEM 1.0 was removed in this version 2 (ASTER GDEMVALIDATION TEAM, 2009 2009).

\subsection{Datasets Processing}

. A $90 \mathrm{~m}$ spatial resolution SRTM DEM. was resampled to 30m ASTER DEM with the same elevation to generate equal spatial resolution for the two datasets, ASTER GDEM and SRTM DEMs data were extracted for the two study areas , and co registered to remove the potential horizontal 
and vertical shifts between the two DEMs with WGS84 projection model .

. The GCP values were compared to ASTER and SRTM DEM data which cover the two study areas (pixel values corresponding to GCPs ) using (Extract Values to Point) tool under GIS Environment.

. Error distribution frequency of $\Delta \mathrm{H}$ between (SRTM DEM or ASTER. GPS) were tested using RMSE

-Aspect and Topographic Position Index (TPI) were created from the two datasets ASTER and SRTM using Arc GIS surface analysis tools to investigate and evaluate their influence on accuracies, where they were used as independent values in Weight Estimation Multiple Regression model

- Accuracy improvement was tested and investigated by comparing standard errors of the estimate (S.E.E.) resulting from multiple regression model using weighted least squares (WLS) (with DEMs, aspect, and TPI as independent variables) and simple linear regression using ordinary least squares (OLS) analysis (with DEMs as a single independent variable). GPS data represented dependent variable in both analyses.

\section{RESULTS AND ANALYSIS}

The histograms of DEMs below illustrate the spread of elevation points values around the mean value (corresponding to GPS points )for each study area separately and in combination. These histograms show that qena region is more variable (wider spread) than for Delta which characterized by long right tail data ( because the variance is sensitive to unusually high or low values, and smaller standard deviation and consequently smaller variance and consequently smaller variability). The mean values for Delta region in table 1: are 44.234 and 47.617 for SRTM and ASTER data respectively and for Qena \& west desert region are 160.9 and 156.2 for SRTM and ASTER data respectively. Standard deviation (SD) are 130.13 and 67.228 for Qena and Delta study areas respectively for SRTM dataset. These mean values explain the topographic nature of these study areas as delta region is almost flat while Qena and west desert region is almost hilly terrain .
Delta : SRTM
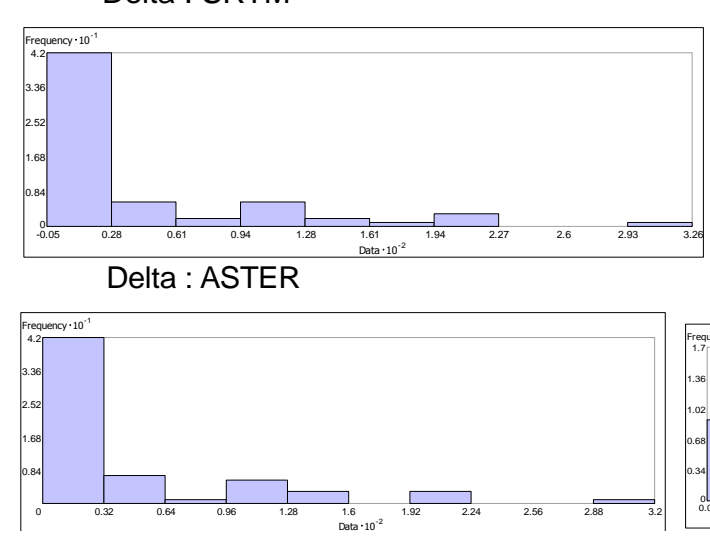

2 Parts : SRTM

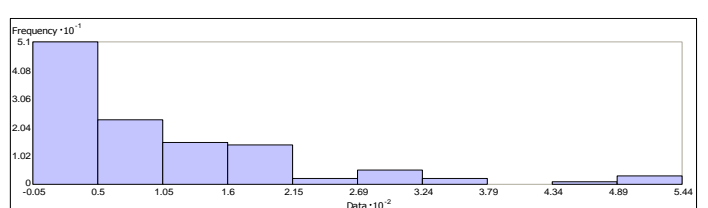

Fig 2: Histograms for SRTM DEM, and ASTER DEM (corresponding to GCP locations) for Delta \& Qena and west desert regions

Qena_h: SRTM

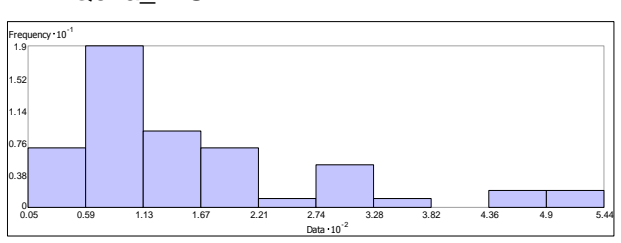

Qena_h : ASTER

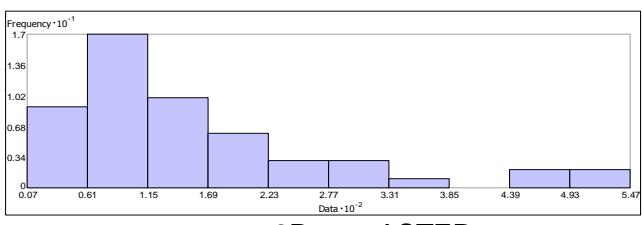

2Parts : ASTER

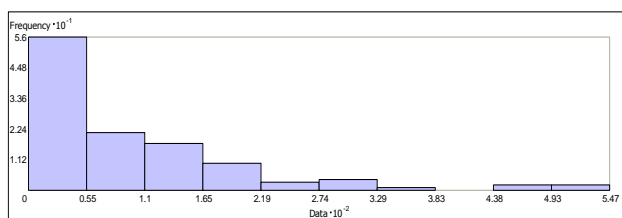

Table 1: ASTER, SRTM, and GPS Statistical analysis among region A, B, combined region

\begin{tabular}{|l|l|l|l|}
\hline $\begin{array}{l}\text { Statistical } \\
\text { parameters }\end{array}$ & $\begin{array}{l}\text { GPS } \\
\text { (Qena\&west desert } \\
\text { region }\end{array}$ & $\begin{array}{l}\text { SRTM } \\
\text { (Qena\&west desert } \\
\text { region) }\end{array}$ & $\begin{array}{l}\text { ASTER } \\
\text { (Qena\&west desert } \\
\text { region) }\end{array}$ \\
\hline Min & 4.399 & 5.334 & 7 \\
\hline Max & 556.42 & 543.61 & 547.23 \\
\hline Mean & 162.12 & 160.9 & 156.2 \\
\hline Std. Dev. & 131.21 & 130.13 & 129.69 \\
\hline Median & 119.93 & 113 & 115.35 \\
\hline Skewness & 1.3969 & 1.445 & 1.4747 \\
\hline
\end{tabular}




\begin{tabular}{|c|c|c|c|}
\hline count & 53 & 53 & 53 \\
\hline $\begin{array}{l}\text { Statistical } \\
\text { parameters }\end{array}$ & $\begin{array}{l}\text { GPS } \\
\text { (Delta region) }\end{array}$ & $\begin{array}{l}\text { SRTM } \\
\text { (Delta region) }\end{array}$ & $\begin{array}{l}\text { ASTER } \\
\text { (Delta region) }\end{array}$ \\
\hline Min & -1.925 & -4.632 & 0.47576 \\
\hline Max & 327.51 & 325.72 & 320.17 \\
\hline Mean & 52.175 & 44.234 & 47.617 \\
\hline Std. Dev. & 66.977 & 67.228 & 65.347 \\
\hline Median & 24.88 & 10.573 & 15.035 \\
\hline Skewness & 1.9295 & 2.0315 & 2.0472 \\
\hline count & 63 & 63 & 63 \\
\hline $\begin{array}{l}\text { Statistical } \\
\text { parameters }\end{array}$ & $\begin{array}{l}\text { GPS } \\
\text { (Two regions) }\end{array}$ & $\begin{array}{l}\text { SRTM } \\
\text { (Two regions) }\end{array}$ & $\begin{array}{l}\text { ASTER } \\
\text { (Two regions) }\end{array}$ \\
\hline Min & -1.925 & -4.6316 & 0.4758 \\
\hline Max & 556.42 & 543.61 & 547.23 \\
\hline Mean & 102.41 & 97.539 & 97.227 \\
\hline Std. Dev. & 115.01 & 116.19 & 113.4 \\
\hline Median & 69.293 & 65.687 & 64.143 \\
\hline Skewness & 1.8364 & 1.8289 & 1.9126 \\
\hline count & 116 & 116 & 116 \\
\hline
\end{tabular}

Measurement of errors in DEMs is often impossible because the true value for every geographic feature or phenomenon represented in a geographic data set is rarely determinable (Goodchild et al. 1994). Uncertainty, instead of error, should be used to describe the quality of a DEM. To analyze the pattern of deviation between two sets of elevation data, conventional ways are to yield statistical expressions of the accuracy, such as the root mean square error, standard deviation, and mean. The most widely used measure is the Root Mean Square Error (RMSE). It measures the dispersion of the frequency distribution of deviations between the original elevation data and the DEM data, mathematically expressed as:

$$
\operatorname{RMSE}_{z}=\sqrt{\frac{1}{n} \sum_{i=1}^{n}\left(z_{d i}-z_{r i}\right)^{2}}
$$

Where: $Z_{\mathrm{di}}$ is the $\mathrm{i}$ elevation value measured on the DEM surface; $Z_{\mathrm{ri}}$ is the corresponding original elevation; $n$ is the number of elevation points checked.

The larger the value of the RMSE, the greater the discrepancy between the two data sets

Standard linear regression models were developed between GPS and the corresponding DEM points values (single independent variable)for the study areas to calculate Std. Error of the Estimate and $\mathrm{R}^{2}$ and RMSE , and the resulted statistical parameters where tabulated in table 2. Standard linear regression analysis reveals strong correlation between (SRTM \& ASTER) and GPS data for the two study areas.

Table 2: SRTM and ASTER vs GPS Statistical Analysis among Region A, B, combined regions

\begin{tabular}{|c|c|c|c|c|c|c|c|c|c|}
\hline $\begin{array}{l}\Delta H \text { between (GPS } \\
\text { and corrosponding } \\
\text { DEM values) for } \\
\text { study areas }\end{array}$ & Count & Min & Max & Mean & Median & RMSE & $\begin{array}{l}\text { Std. Error of } \\
\text { the Estimate } \\
\text { For regression } \\
\text { line }\end{array}$ & $\mathbf{R}^{2}$ & Skewness \\
\hline $\begin{array}{lll}\text { Delta } & \text { (GPS } \\
\text { SRTM) } & \end{array}$ & 63 & -7.2121 & 62.197 & 7.9413 & 2.6757 & 15.63063 & 13.584 & $\begin{array}{l}0.96 \\
0\end{array}$ & 1.8057 \\
\hline $\begin{array}{l}\text { Delta (GPS - } \\
\text { ASTER) }\end{array}$ & 63 & $\begin{array}{l}- \\
13.687 \\
\end{array}$ & 43.727 & 4.558 & 1.8542 & 13.16037 & 12.538 & .966 & 1.2277 \\
\hline $\begin{array}{lcr}\begin{array}{l}\text { Qena } \\
\text { desert }\end{array} & \begin{array}{r}\text { west } \\
\text { region })\end{array} \\
(\text { GPS . SRTM } & \text { SR }\end{array}$ & 53 & $-\overline{8}-3735$ & 28.575 & 1.2144 & $\begin{array}{l}- \\
0.93479\end{array}$ & 7.86844 & 7.879 & .996 & 1.2044 \\
\hline
\end{tabular}




\begin{tabular}{|c|c|c|c|c|c|c|c|c|c|}
\hline $\begin{array}{l}\text { (Qena } \& \text { west } \\
\text { desert } \\
\text { (GPS } \\
\text { (GSTERion) }\end{array}$ & 53 & $\begin{array}{l}- \\
13.769\end{array}$ & 43.327 & 5.9186 & 6.565 & 12.35722 & 11.006 & .993 & 0.72677 \\
\hline $\begin{array}{l}\text { Combined regions } \\
\text { (GPS-SRTM) }\end{array}$ & 116 & $\begin{array}{l}- \\
8.3735\end{array}$ & 62.197 & 4.8678 & 1.3334 & 12.68766 & 11.685 & .990 & 2.0206 \\
\hline $\begin{array}{l}\text { Combined regions } \\
\text { (GPS -ASTER) }\end{array}$ & 116 & $\begin{array}{l}- \\
13.769\end{array}$ & 43.727 & 5.1797 & 3.091 & 12.79967 & 11.7624 & .990 & 1.0248 \\
\hline
\end{tabular}

Since SRTM and ASTER data are available worldwide and it is hard to obtain specific field verification data everywhere ( to be sure for the accuracy of these free DEMs and its suitability for certain project ), so use of developed and updated regression curves in various regions can become a practical tool for SRTM or ASTER applications in applied science.

Standard (or ordinary) linear regression models assume that variance is constant within all DEM dataset. The variance of the data is the average squared deviation of all elevation values from the mean, and the calculated variance is sensitive to unusually high or low values . In this study, in Qena ,Delta, and in combination, the variance is not constant as the heights values are varying in some areas ( due to different topographic terrain in the same region (where the Nile pass through the two regions, also there are valleys area around the Nile for regions A and B and there are several mountains and hills which present in East Sahara and West Sahara in Region B and on the boundary area of Region A) so linear regression using ordinary least squares (OLS) no longer provides optimal model estimates. If the differences in variability can be predicted from another variable, the Weight Estimation procedure can compute the coefficients of a linear regression model using weighted least squares (WLS) (SPSS vrs15 Help). Weight Estimation procedure tests a range of weight transformations and indicates which will give the best fit to the data.

The developed approach use Aspect and Topographic Position Index (TPI ) as independent variables in WLS model, and use TPI as an weight variable for all tested models ( using weight function deduced from ASTER DEM ,where the horizontal resolution is better $=30 \mathrm{~m}$ )

\section{Weight Function = 1/ $($ Weight Variable(AsterDEM)) **power}

Where power range from -2 to 2 by 0.5

Aspect identifies the downslope direction of the maximum rate of change in value from each cell to its neighbors and the Topographic Position Index (TPI) is the basis of the classification system and is simply the difference between a cell elevation value and the average elevation of the neighborhood around that cell. Positive values mean the cell is higher than its surroundings while negative values mean it is lower. The degree to which it is higher or lower, plus the slope of the cell, can be used to classify the cell into slope position. If it is significantly higher than the surrounding neighborhood, then it is likely to be at or near the top of a hill or ridge. Significantly low values suggest the cell is at or near the bottom of a valley. TPI values near zero could mean either a flat area or a mid-slope area, so the cell slope can be used to distinguish the two(Weiss 2001; Jones et al. 2000).

\subsection{Accuracy Improvement}

Accuracy improvement was ascertained by comparing standard errors of the estimate (S.E.E.) resulting from Weight Estimation Regression models (with SRTM or ASTER, aspect, and TPI(weight variable) as independent variables ) and linear regression analysis (with SRTM or ASTER as a single independent variable). GPS data represented dependent variable in both analyses. In all cases, application of Weight Estimation Regression models resulted in smaller S.E.E.

Table 3: linear regression model using WLS, Std. Error of the Estimate, and $\mathrm{R}^{2}$

\begin{tabular}{|c|c|c|c|}
\hline Study area / Models & ( linear regression model using weighted least squares (WLS) & $\begin{array}{l}\text { Std. Error } \\
\text { of the } \\
\text { Estimate }\end{array}$ & $\mathrm{R}^{2}$ \\
\hline $\begin{array}{lll}\text { Delta } & \text { /SRTM } & \text { DEM } \\
\text { Model }\end{array}$ & $\begin{array}{l}\mathrm{Y}=\mathrm{a}+\mathrm{bx}_{1}+\mathrm{cx}_{2} \\
\mathrm{GPS}=.3 .301+0.967 *(\mathrm{SRTM})+3.625 *(\mathrm{TPI})\end{array}$ & 9.502 & .965 \\
\hline $\begin{array}{l}\text { Delta /ASTER DEM } \\
\text { Model }\end{array}$ & $\begin{array}{l}\mathrm{Y}=\mathrm{a}+\mathrm{bx}_{1}+\mathrm{cx}_{2}+\mathrm{d} \mathrm{x}_{3} \\
\mathrm{GPS}=1.264+1.005 *(\text { ASTER })-.023 *(\text { Aspect })+1.998 *(\mathrm{TPI})\end{array}$ & 9.101 & .968 \\
\hline $\begin{array}{lll}\text { (Qena\&west } & \text { desert } \\
\text { region)/ SRTM } & \text { DEM } \\
\text { Model } & & \end{array}$ & $\begin{array}{l}\mathrm{Y}=\mathrm{a}+\mathrm{bx}_{1}+\mathrm{cx}_{2}+\mathrm{d} \mathrm{x}_{3} \\
\mathrm{GPS}=-10.887+.998 *(\mathrm{SRTM})+.027 *(\text { Aspect })+2.145 *(\mathrm{TPI})\end{array}$ & 1.725 & .999 \\
\hline
\end{tabular}




\begin{tabular}{|l|l|l|l|}
\hline $\begin{array}{l}\text { (Qena\&west desert } \\
\text { region)/ ASTER DEM } \\
\text { Model }\end{array}$ & $\begin{array}{l}\mathrm{Y}=\mathrm{a}+\mathrm{bx}_{1}+\mathrm{cx}_{2} \\
\mathrm{GPS}=4.514+0.997 *(\mathrm{ASTER})+0.512 *(\mathrm{TPI})\end{array}$ & 5.769 & .995 \\
\hline $\begin{array}{l}\text { Two regions/ SRTM } \\
\text { DEM model }\end{array}$ & $\begin{array}{l}\mathrm{Y}=\mathrm{a}+\mathrm{bx}_{1}+\mathrm{cx}_{2}+\mathrm{d} \mathrm{x_{3 }} \\
\mathrm{GPS}=-4.268+0.980 *(\mathrm{SRTM})+.018 *(\text { Aspect })+2.202 *(\mathrm{TPI})\end{array}$ & 5.930 & .992 \\
\hline $\begin{array}{l}\text { Two regions /ASTER } \\
\text { DEM model }\end{array}$ & $\begin{array}{l}\mathrm{Y}=\mathrm{a}+\mathrm{bx}_{1}+\mathrm{cx}_{2} \\
\mathrm{GPS}=0.189+1.006 *(\text { ASTER })+1.241 *(\mathrm{TPI})\end{array}$ & 8.520 & .991 \\
\hline
\end{tabular}

Table 3 describe the developed multiple linear regression models using weighted least squares (WLS) for SRTM and ASTER datasets among study areas A , B and in combination, and the improved Std. Error of the Estimate and $\mathrm{R}^{2}$. The developed multiple regression models reducedthe SEE for Delta from 13.584 to 9.502 for SRTM dataset and from 12.538 to 9.101 for ASTER dataset For (B) SEE reduce from 7.879 to 1.725 for SRTM dataset and from 11.006 to 5.769 for ASTER dataset .TPI and Aspect of the terrain was found to have influence on the errors in SRTM and ASTER datasets. Also it was noticed from the tables 2 and 3 that $\mathrm{R}^{2}$ where increased relatively.

\section{CONCLUSIONS}

Analyses presented in this paper indicated that Absolute vertical accuracy of SRTM and ASTER data for A and B study areas proved to be less than the value of $16 \mathrm{~m}$ and 17 $\mathrm{m}$ presented in the original SRTM and ASTER requirement specification respectivly. Both TPI and Aspect characteristics of the terrain have significant impact on accuracy of SRTM and ASTER data. Accuracy particularly suffers on terrains with ( ridge TPI ). Influence of the vegetation cover Delta region was not assessed in this study, and it is assumed that in both geographic areas vegetation covers uniformly and hence the associated error would be constant and, therefore, would not affect the regression models. The results of accuracy assessment depend on the number of GPS readings per one spatial unit of SRTM and ASTER data. The more GPS readings would be available, the more accurate the final estimation will be.

\section{REFERENCES}

[1]. Renschler C S; Flanagan D C; Engel B A; Kramer L A; Sudduth K A (2002). Site-specific decision-making based on RTK GPS survey and six alternative elevation data sources: watershed topography delineation. Transactions of the ASABE, 45(6), 1883-1895.

[2]. Martinez-Casasnovas J A (2003). A spatial information technology approach for the mapping and quantification of gully erosion. Catena, 50(2-4), 293-308.

[3]. Kravchenko A N; Bullock D G (2000). Correlation of corn and soybean grain yield with topography and soil properties.Agronomy Journal, 92, 75-83.

[4]. Kaspar T C; Colvin T S; Jaynes D B; Karlen D L; James D E; Meek D W; Pulido D; Butler H (2003). Relationship between six years of corn yields and terrain attributes. Precision Agriculture, 4(1), 87-101.

[5]. BERNHARD, R., MICHAEL, E., ACHIM, R. and RICHARD, B., 2003, The shuttle radar topography mission - a new class of digital elevation models acquired by spaceborne radar. ISPRS Journal of Photogrammetry \& Remote Sensing, 57, pp. 241-262.

[6]. JARVIS, A., REUTER, H.I., NELSON,A.andGUEVARA, E., 2008, Hole-filled SRTM for the globe, Version 4, available from the CGIAR-CSI SRTM 90 m. Available online at:

http://srtm.csi.cgiar.org (accessed 5 March 2010).

[7]. GOROKHOVICH,Y and VOUSTIANIOUK, A., 2006, Accuracy assessment of the processed SRTM-based elevation data by CGIAR using field data from USA and Thailand and its relation to the terrain characteristics. Remote Sensing of Environment, 104, pp. 409-415

[8]. GEORGE, C.M. and CHARALAMPOS, V. E.P., 2005, Vertical accuracy of the SRTM DTED level 1of Crete. International Journal of Applied Earth Observation and Geoinformation, 7, pp. 49-59.

[9]. BERRY, P.A.M., GARLICK, J.D. and SMITH, R.G., 2007, Near-global validation of the SRTM DEM using satellite radar altimetry. Remote Sensing of Environment, 106, pp. 17-27.

[10]. ASTER GDEMVALIDATION TEAM, 2009, ASTER Global DEMValidation Summary Report. Available online at:

http://www.ersdac.or.jp/GDEM/E/image/ASTERGDEM_

ValidationSummaryReport_Ver1.pdf (accessed 10 March 2010).

[11]. Papasaika, H. and Baltsavias, E., 2009. Fusion of LiDAR and Photogrammetric Generated Digital Elevation Models. In: Proceedings of the ISPRS Hannover Workshop on High-Resolution Earth Imaging for Geospatial Information, Hannover, Germany.

[12]. Papasaika, H., Kokiopoulou, E., Baltsavias, E., Schindler, K. and Kressner, D., 2011. Fusion of Digital Elevation Models Using Sparse Representations. In: Proceedings of the Photogrammetric Image Analysis, Munich, Germany.

[13]. Honikel, M., 1999. Strategies and methods for the fusion of digital elevation models from optical and SAR data. In: International Archives of Photogrammetry and Remote Sensing, 32(7-4-3W6), pp. 83-89.

[14]. Gamba, P., Dell'Acqua, F. and Houshmand, B., 2003. Comparison and fusion of Lidar and InSAR digital elevation 
models over urban areas. International Journal of Remote Sensing, 24(22), pp. 4289-4300.

[15]. Podobnikar, T., 2006. DEM from various data sources and geomorphic details enhancement. In: 5th ICA Mountain Cartography Workshop.

[16]. Costantini, M., Malvarosa, F., Minati, F. and Zappitelli, E., 2006. A Data Fusion Algorithm for DEM Mosaicking: Building a Global DEM with SRTM-X and ERS Data. In: Proccedings of the Geo, science and Remote Sensing Symposium, 2006. IGARSS 2006. pp. 3844-3847.

[17]. ShiWZ, Tian Y (2006) A hybrid interpolation method for the refinement of a regular grid digital elevation model. Int J Geogr Inf Sci 20:53-67

[18]. Sun, G., Ranson, K. J., Kharuk, V. I., \& Kovacs, K. (2003). Validation of surface height from shuttle radar topography mission using shuttle laser altimeter. Remote Sensing of Environment, 88, 401-411.

[19]. Miliaresis, G. Ch., \& Paraschou, C. V. E. (2005). Vertical accuracy of the SRTM DTED level 1 of crete. International Journal of Applied Earth Observation and Geoinformation, 7(1), 49-59.

[20]. SRTM 90m Digital Elevation Database v4.1. http://www.cgiar-csi.org/data/srtm-90m-digital-elevationdatabase-v4-1, as accessed on 30th of Sep-tember, 2013 [21]. ASTER GDEMVALIDATION TEAM, 2009, ASTER Global DEMValidation Summary Report. Available online at:

http://www.ersdac.or.jp/GDEM/E/image/ASTERGDEM_

ValidationSummaryReport_Ver1.pdf (accessed 10 March 2010).

[22]. Goodchild MF, Buttenfield BP, Wood J (1994) Introduction to visualizing data quality. In: Hearshaw HM, Unwin DJ (eds) Visualization in Geographic Information Systems. John Wiley and Sons, New York, pp 141-149

[23]. SPSS vers 15 help

[24]. Weiss, A. 2001. Topographic Position and Landforms Analysis. Poster presentation, ESRI User Conference, San Diego, CA. Available, by permission from the author, at http://www.jennessent.com/arcview/TPI_Weiss_poster.htm. [25]. Jones , K.B., D.T. Heggem, T.G. Wade, A.C. Neale, D.W. Ebert, M.S. Nash, M.H.. 2000. Assessing Landscape Conditions Relative to Water Resources in the Western United States: A Strategic Approach. Environmental Monitoring and Assessment 64: 227 - 245. 